\title{
ZINC FERTILIZATION EFFECTS ON AGRO- MORPHOLOGICAL AND QUALITY PARAMETERS OF COMMONLY GROWN RICE
}

\author{
B. Saha ${ }^{*}$, S. Saha, P. D. Roy ${ }^{1}$ and G. C. Hazra and Arpita Das ${ }^{2}$ \\ Directorate of Research, Bidhan Chandra Krishi Viswavidyalaya, Kalyani, Nadia \\ West Bengal - 741 235, India
}

\begin{abstract}
Among the micronutrients, zinc deficiency is widespread throughout the world particularly in low land rice fields causing low yields and affecting nutritional quality of the produce. In present investigation, 26 rice cultivars including some locals, aromatics, HYVs and hybrids grown on an Inceptisols with no Zn, basal Zn and soil+foliar applied Zn were evaluated for agro-morphological and quality parameters in a strip plot design having three replications during kharif season for consecutive two years (2009 and 2010). Rice cultivars differed significantly in their native agro-morphological parameters as well as among cultivar categories. Grain and straw yield as well as harvest index of different cultivars showed wide variations both with and without $\mathrm{Zn}$ application. On average, grain yields of different rice cultivars increased by $29 \%$ and $22 \%$ with soil plus foliar and only soil application of $\mathrm{Zn}$, respectively. Regarding yield efficiency, HYV showed highest efficiency followed by hybrid, aromatic and local cultivars, irrespective of $\mathrm{Zn}$ fertilization. Applications of $\mathrm{Zn}$, both as basal and as soil+foliar application significantly reduced the Fe content in brown rice irrespective of the cultivar grown.
\end{abstract}

Key words: Rice cultivars, agro-morphological parameters, zinc, iron, brown rice

\section{INTRODUCTION}

Micronutrient malnutrition affects nearly one-third of the world populations, particularly in developing and under-developed countries (Alloway, 2004). Among the micronutrients, $\mathrm{Zn}$ and Fe deficiencies are of major concern, not only in crop

\footnotetext{
* Corresponding author email: bnsaha1@gmail.com

${ }^{1}$ Jute Research Station, Bihar Agricultural University, Katihar, Bihar - 854 105, India

${ }^{2}$ College of Horticulture, Bihar Agricultural University, Noorsarai, Nalanda, Bihar - 803 113, India
} 
production point of view but also in animal and human nutrition. Zinc deficiency in lowland rice (Oryza sativa L.) fields occurred due to its chemical precipitation with sesquioxides and rendering it unavailable to plants (Mandal et al., 1992). Hence, lowland rice fields having marginal or medium status of available $\mathrm{Zn}$ could become Zn deficient under waterlogged conditions (Dobermann and Fairhurst, 2000). Response of rice crop to applied Zn towards yield increments as well as grain Zn enrichment was observed in India (Singh, 2009), Bangladesh (Rahman et al., 2008), Turkey (Cakmak, 2008) and China (Zou et al., 2007). Possibly, the cultivars also differ in their response to zinc fertilization in Zn-deficient soil. Genotypic variations in Zn uptake and utilization in Zn deficient soils have also been reported (Graham and Rengel, 1993; Fageria et al., 2002). An attempt has been made in this study to screen out twenty six rice cultivars including some locals, HYVs, hybrids and aromatics popularly grown in Indian subcontinent as to their important agromorphological and quality parameters.

\section{MATERIALS AND METHODS}

The study was conducted in kharif season (summer) for the consecutive two years (2009 and 2010) at the Central Research Farm of Bidhan Chandra Krishi Viswavidyalaya, Kalyani, West Bengal, India located at $22^{0} 58.114^{\prime} \mathrm{N}$ latitude and $88^{0} 29.543^{`}$ E longitude. The experimental plot remained fallow for last ten years and soils of the experimental plot had clay loam texture, pH 6.6 (Page et al., 1982), organic carbon $8.9 \mathrm{mg} \mathrm{kg}^{-1}$ (Walkley and Black, 1934), available Fe $215.8 \mathrm{mg} \mathrm{kg}^{-1}$, available $\mathrm{Mn} 16.0 \mathrm{mg} \mathrm{kg}^{-1}$, available $\mathrm{Zn} 0.7 \mathrm{mg} \mathrm{kg}^{-1}$ (marginally deficient since, critical limit of available $\mathrm{Zn}$ for anaerobic rice is $0.8 \mathrm{mg} \mathrm{kg}^{-1}$ ) and available $\mathrm{Cu} 6.0$ $\mathrm{mg} \mathrm{kg}^{-1}$ (Lindsay and Norvell, 1978). Twenty six popularly grown rice cultivars including two locals, four aromatics, seventeen high yielding varieties (HYVs) and three hybrids with wide genetic variations were raised with standard management practices. Agro climatic parameters like rainfall, expand $T_{\max }$, expand $T_{\min }$. and relative humidity prevailed over the location during June to September were 1265 $\mathrm{mm}, 32.0^{\circ} \mathrm{C}, 26.3^{\circ} \mathrm{C}$ and $97 \%$ during 2009 and $987 \mathrm{~mm}, 32.6^{\circ} \mathrm{C}, 25.1^{\circ} \mathrm{C}$ and $94 \%$ during 2010 respectively Paddy seeds were sown in a nursery bed following standard method. During nursery bed preparation the soil was puddled with the help of country plough. On the next day, nursery area was divided into narrow beds of $1 \mathrm{~m}$ width and $10 \mathrm{~m}$ length. Drainage channel (30 cm wide) was made in between the seed beds. Urea and SSP were applied @ 22.5 and $50 \mathrm{~g} / \mathrm{m}^{2}$, respectively. Three hand full seeds were uniformly broadcasted on the seed bed. The seed bed was saturated with water for first four days and then water level was increased gradually up to $5 \mathrm{~cm}$ as the seedlings started to grow. Seedlings were transplanted in the main field at the age of 25 days. Flood irrigation was done depending on rainfall during the growth period of the crop. Three $\mathrm{Zn}$ treatments viz., no $\mathrm{Zn}\left(\mathrm{Zn}_{0}\right)$, $\mathrm{Zn} @ 20 \mathrm{~kg} \mathrm{ha}^{-1}$ as zinc sulphate heptahydrate $\left(\mathrm{ZnSO}_{4} \cdot 7 \mathrm{H}_{2} \mathrm{O}\right)$ as basal $\left(\mathrm{Zn}_{1}\right)$ and $\mathrm{Zn} @ 20 \mathrm{~kg} \mathrm{ha}^{-1}$ as basal + two foliar sprays $\left(\mathrm{Zn}_{2}\right)$ - one at pre-flowering and another at grain forming stage @ 
$0.5 \% \mathrm{ZnSO}_{4} .7 \mathrm{H}_{2} \mathrm{O}$ were imposed. Zinc fertilizer was applied to soil at the time of land preparation through broadcasting followed by surface incorporation. Treatments were imposed in a strip plot design having three replications. Foliar application of $\mathrm{Zn}$ was practiced with a Knapshack sprayer (volume 14 litre) @ $4.42 \mathrm{~kg} \mathrm{ZnSO}_{4} .7 \mathrm{H}_{2} \mathrm{O}$ $\mathrm{ha}^{-1}$ at evening hours of the daytime. As the rice cultivars varied widely in their genetic make-up, initiation of flowering was at different times in the growing season, therefore spraying was done at different days after transplanting according to the initiation of flowering. NPK fertilizers were applied as per the recommended dose in all the plots of the experimental field (80:40:40). Half of the dose of nitrogen was applied at the time of transplanting (through IFFCO::10:26:26 and urea) and the other half at tillering stage (through urea). The entire amount of $\mathrm{P}$ and $\mathrm{K}$ were applied at the time of transplanting (as IFFCO::10:26:26). The brown plant hopper (Nilaparvata lugens) and gundhy bug (Leptocorisa acuta) have been observed as major pests of rice during early crop establishing and milky stages, respectively. The Imidachloprid @100 ml ha ${ }^{-1}$ and Carbaryl @ $25 \mathrm{~kg} \mathrm{ha}^{-1}$ were used on the crop and found to be most effective against BPH and gundhy bug infesting rice, respectively.

At maturity, the rice cultivars were harvested plot-wise and representative samples of grains were collected and subsequently processed for dry-ashing and then concentration of $\mathrm{Zn}$ and $\mathrm{Fe}$ in brown rice was measured by using an atomic absorption spectrophotometer (GBC Avanta). Important agro-morphological parameters of rice cultivars viz. number of tillers per hill at maximum tillering stage; plant height, panicle length (considering eight number of hills in each plot and their mean values were presented), test weight (thousands grain weight), grain and straw yields of each cultivars were measured plot-wise for the consecutive two years i.e. 2009-10 and 2010-11. Harvest index (HI) of different cultivars was calculated as grain yield divided by biomass yield (grain yield+straw yield).

Analysed data of the aforesaid trial pooled for the consecutive two years i.e. 2009 and 2010 are presented. Design of the experiment followed for statistical analysis was strip plot. Statistical analyses of the data for comparison among the treatments were done using SPSS 10.0 software package.

\section{RESULTS AND DISCUSSION}

\section{Number of tillers per hill at tillering stage}

Number of tillers per hill varied widely among the cultivars as well as within the categories of the cultivars and among the different categories of the cultivars, it was higher in hybrids followed by HYV, aromatics and locals irrespective of $\mathrm{Zn}$ application. Results further depicted higher number of tillers per hill from Zn treated plots compared to untreated control irrespective of the rice cultivars. On an average, number of tillers per hill of the tested cultivars varied from 9.7 to 22.8 with a mean value of 15.0 (Table 1). The highest number of tillers per hill (22.8) was recorded in the cv. Satabdi, a high yielding cultivar with basal application of Zn fertilizers but the 
lowest number (9.7) was recorded in the cultivar IR 64, a high yielding cultivar in untreated control. On an average, $17 \%$ increase in the number of tillers per hill was found with basal application of $\mathrm{Zn}$ over control.

\section{Plant height of the rice cultivars}

Results revealed that Zn application through both soil and soil plus foliar applications resulted a significant increase in plant height over control. The magnitude of such increase was higher with soil plus foliar application of Zn than only soil application irrespective of the cultivars tested. Among the rice cultivars, the highest value $(203.1 \mathrm{~cm})$ was recorded in Kalma 222, a local cultivar and the lowest $(92.9 \mathrm{~cm})$ was in IR 64, a high yielding cultivar. Results also revealed that there was an increase in its height to the tune of 3.6 and $7.3 \%$ with soil and soil+foliar application of Zn respectively over control (Table 1). Regarding different categories of the cultivars, results also showed that it was higher with locals followed by aromatics, HYVs and hybrids irrespective of Zn application methods.

\section{Panicle length of the rice cultivars}

Like plant height, panicle length of rice cultivars was also influenced significantly by Zn levels as well as genotypes. Its magnitude varied from 19.8 to $33.7 \mathrm{~cm}$ with a mean value of $25.5 \mathrm{~cm}$ (Table 1). Results also showed that $\mathrm{Zn}$ application, on an average, caused an increase in its amount over control to the magnitude of $5.6 \%$ and $10.2 \%$ in soil $\mathrm{Zn}$ and soil plus foliar $\mathrm{Zn}$ respectively, irrespective of cultivars. So, from the results it can be opined that soil plus foliar application of $\mathrm{Zn}$ is conducive for increasing the panicle length. These results are in line with Bandara and Silva (2000) who reported an increase of $7 \%$ panicle length upon application of $2.5 \mathrm{~kg} \mathrm{Zn} \mathrm{ha}^{-1}$, while Fageria and Baligar (2005) showed significant genotypic variations among the rice genotypes upon application of $\mathrm{Zn}$ fertilizers as well as without $\mathrm{Zn}$ application. Results also showed that among the different categories of the cultivars $\mathrm{Zn}$ application was very effective in case of hybrid followed by aromatic, local and HYV.

\section{Test weight (g) of the rice cultivars}

Test weights (thousand grain weight) of the rice cultivars were measured after drying (at $50^{\circ} \mathrm{C}$ ) of the harvested grains containing 12-13\% moisture. Results (Table 2) of test weight corroborated with those of panicle length, where it was found that Zn application caused a significant increase over control. Results further showed that similar to panicle length, soil plus foliar application was superior to only soil application. Panicle length varied from 95.3 to $293.3 \mathrm{~g}$ with a mean value of $199.1 \mathrm{~g}$ irrespective of cultivars and Zn application (Table 2). Results also showed that Zn application, on an average, caused an increase in panicle length to the tune of 3.9\% and 5.3\% in soil and soil plus foliar application of Zn respectively. Regarding relative efficiency about test weight of the different categories of the cultivars results showed that HYVs were more effective followed by hybrids, aromatics and locals. Bandara 
and Silva (2000) reported 3.6\% increase in test weight with application of $2.5 \mathrm{~kg} \mathrm{Zn}$ $\mathrm{ha}^{-1}$, while Rahman et al. (2008) reported an increase in test weight upon Zn application @ 1.5 and 3.0 kg Zn ha ${ }^{-1}$ but the effect was found non-significant. Similar trend of result was also reported by Pal et al. (2008). Increased test weight of rice cultivars upon $\mathrm{Zn}$ fertilization might be due to its involvement in the carbonic anhydrase activity and more carbohydrate accumulation in seeds.

\section{Yield and harvest index (HI) of the rice cultivars}

Grain and straw yields recorded the similar trend of results like those of plant height and test weight where results showed a significant increase in their amounts upon $\mathrm{Zn}$ application. Results also showed that effect of $\mathrm{Zn}$ was further influenced by the method of application i.e. soil and soil plus foliar applications irrespective of the cultivars grown. Soil plus foliar application of Zn caused a significant increase in grain yield not only over control but also over only soil application of $\mathrm{Zn}$. Highest grain yield was recorded with HYVs followed by hybrids>aromatics $>$ locals. On an average, grain yield of rice cultivars varied from 10.8 to $35.3 \mathrm{q} \mathrm{ha}^{-1}$ in locals and HYVs respectively when grown in native soil deficient in Zn. Highest grain yield of $66.7 \mathrm{q} \mathrm{ha}^{-1}$ as well as lowest grain yield of $12.8 \mathrm{q} \mathrm{ha}^{-1}$ was recorded in Swarna, a HYV and Kalma 222, a local cultivar respectively with application of soil +foliar spraying of Zn fertilizers (Table 2). The magnitude of increase in its amount over control was $29 \%$ and $22 \%$ in soil plus foliar and only soil application of $\mathrm{Zn}$ respectively. Therefore, it can be opined that soil plus foliar application of Zn was very effective than soil alone application. Regarding yield efficiency, HYVs showed the highest performance followed by hybrid, aromatic and local irrespective of $\mathrm{Zn}$ applications. Highest grain yield in HYVs than other cultivars might be related to their physiological efficiency, since $\mathrm{Zn}$ being metallic co-factor of a number of enzyme proteins influencing such activities in plants e.g. carbonic anhydrase and a number of dehydrogenases (Vallee and Wacker, 1970). Increased grain yield of $16.5 \%$ upon application of $2.5 \mathrm{~kg} \mathrm{Zn} \mathrm{ha}^{-1}$ was reported by Bandara and Silva (2000) while $15 \%$ increase in grain yield upon application of $5 \mathrm{~kg} \mathrm{Zn} \mathrm{ha}^{-1}$ was reported by Rahman et al. (2008); a significant increase in grain yield upon Zn fertilization and its variations among the upland rice cultivars was also reported by Fageria and Baligar (2005).

Straw yield (Table 2), on the other hand, was higher in locals (135.6 q ha ${ }^{-1}$ ) followed by hybrids (113.5 q ha ${ }^{-1}$ ), aromatics (107.0 q ha-1) and HYVs (86.0 q ha-1). On an average, its magnitude varied from $47.9 \mathrm{q} \mathrm{ha}^{-1}$ to $145.1 \mathrm{q} \mathrm{ha}^{-1}$ with a mean value of $90.2 \mathrm{q} \mathrm{ha}^{-1}$ (Table 2). Results also showed that upon $\mathrm{Zn}$ application, magnitude of increase in straw yield was less than that of grain yield, where it recorded $12 \%$ and $17 \%$ increase over control in soil plus foliar and only soil application of $\mathrm{Zn}$ respectively. Results, therefore, revealed that $\mathrm{Zn}$ application was very effective to increase the grain yield compared to straw yield. 
Harvest index (HI) i.e. transfer of photosynthates from shoot to grain of the cultivars was also estimated and the results revealed that $\mathrm{Zn}$ application recorded an increase in HI over control and the magnitude of increase was higher with soil plus foliar (7.5\%) than soil alone application (6.3\%) of Zn (Figure 1). Results also showed that among the different categories of the cultivars, HYVs were very efficient to transfer the photosynthates from shoot to grain followed by hybrids, locals and aromatics and this result was in corroboration with the grain yields of the cultivars discussed earlier. Results further revealed that HI values varied widely among the cultivars and it ranged from 0.085 to 0.509 with a mean value of 0.296 . According to photosynthate translocation efficiency (i.e. HI) cultivars were grouped into four classes: very low HI i.e. < 0.2 (FR 43B, Kalma 222, Badshabhog, PA 6444, PHB 71, Gayasur and Gobindabhog), low HI i.e. 0.2-0.3 (Sabita, Lalat, Samba masuri sub1, Samba masuri, IR 64, Bhudev and PNR 546), medium HI i.e. 0.3-0.4 (Satya, Swarna, Satabdi, IR 36, Swarna sub1, Triguna, KRH 2, PNR 519, Khitish and Rasi) and high HI i.e. > 0.4 (GB2 and GB1). Results revealed that increased HI of rice was associated with higher $\mathrm{Zn}$ concentration in grains. The higher HI of the latter groups of cultivars recorded a greater amount of $\mathrm{Zn}$ in grains than the former groups upon soil+foliar application of $\mathrm{Zn}$. This trend was just the reverse in only soil applied $\mathrm{Zn}$ fertilizers excepting with low HI (0.2-0.3) grouped cultivars (Figure 2).

\section{Influence of $\mathrm{Zn}$ fertilization on $\mathrm{Zn}$ concentration in brown rice}

On an average, $\mathrm{Zn}$ concentration in brown rice of the tested cultivars varied from $22.9 \mathrm{mg} \mathrm{kg}^{-1}$ to $79.7 \mathrm{mg} \mathrm{kg}^{-1}$ with a mean value of $40.3 \mathrm{mg} \mathrm{kg}^{-1}$ (Table 3). Results showed that $\mathrm{Zn}$ concentration in brown rice was higher in aromatics (32.0 $\mathrm{mg}$ $\mathrm{kg}^{-1}$ ) followed by HYVs (29.3 mg kg-1), locals (29.0 mg kg-1) and hybrids (25.9 mg

$\mathrm{kg}^{-1}$ ). Results also showed that Zn content in brown rice varied significantly not only among the cultivars but also within the different categories of the cultivars. Most of the aromatic rice species, such as Jasmine and Basmati types, are high in both Fe and Zn (Senasdhira and Graham, 1999; Graham et al., 1999; Yang et al., 2007). Methods of $\mathrm{Zn}$ applications also showed significant variation between them and its magnitude was higher with soil plus foliar application of $\mathrm{Zn}$ than only soil application irrespective of the cultivars grown. Zinc application in soil increased the $\mathrm{Zn}$ concentration in brown rice to the level of $5.0 \mathrm{mg} \mathrm{kg}^{-1}(17 \%)$ over the control; whereas, soil plus foliar applied Zn increased the same to the tune of $27.8 \mathrm{mg} \mathrm{kg}^{-1}$ (95\%) than no $\mathrm{Zn}$ treatment. Approximately two to three folds increase in grain $\mathrm{Zn}$ concentration upon soil plus foliar application was also observed by Cakmak (2008). Among the different categories of the cultivars $\mathrm{Zn}$ content in brown rice was higher with hybrid followed by local, HYV and aromatic upon soil plus foliar application of Zn. Highest increase in grain Zn content with soil+foliar application of Zn was found in Hybrids followed by HYVs than locals and aromatics. 


\section{Influence of $\mathrm{Zn}$ on Fe concentration in brown rice}

As localization of $\mathrm{Fe}$ in rice kernel occurs in the surface bran layer and in embryo region, brown rice could be a good source of $\mathrm{Fe}$ for anaemic patients worldwide. Screening of rice cultivars as to their high Fe content in brown rice could be utilized in breeding purpose for production of high Fe containing transgenic rice cultivars. Loss of this Fe occurred to the extent of $65-70 \%$ during milling and this loss also varied among rice cultivars depending on size and shape of the rice kernel. So, white rice or polished rice would not be a good indicator of Fe availability to consumers. The present experiment also showed that Fe content in brown rice varied widely not only among the cultivars but also within the different categories of the cultivars. Results (Table 3) showed that Fe content in brown rice varied from 50.0 to $62.9 \mathrm{mg} \mathrm{kg}^{-1}$ with a mean value of $54.4 \mathrm{mg} \mathrm{kg}^{-1}$. Native Fe content in brown rice of the tested rice cultivars was as follows: aromatics $\left(72.0 \mathrm{mg} \mathrm{kg}^{-1}\right)$ locals $\left(66.9 \mathrm{mg} \mathrm{kg}^{-}\right.$ ${ }^{1}$ ), hybrids (58.0 mg kg-1) and HYVs (56.4 mg kg-1). Results further showed that application of $\mathrm{Zn}$ caused a significant decrease in grain Fe content over the control, irrespective of the cultivars and the magnitude of decrease was higher with soil plus foliar application of Zn (17.4\%) than with only soil application (9.4\%). Goirdano and Mortvedt (1972) also reported the antagonistic effect of $\mathrm{Zn}$ on Fe nutrition of rice regarding translocation within the plant as the pathway for $\mathrm{Zn}$ and Fe movement is same. Higher Fe content in grains of locals and aromatic cultivars than others might be due to high iron chelating phytosiderophore secretion from roots (Cakmak et al., 1996; Rengel et al., 1998) and more efficient utilization of iron from high iron containing soils (215 $\mathrm{mg} \mathrm{kg}^{-1}$ DTPA extractable Fe) of this region.

\section{CONCLUSIONS}

From the overall results it could be concluded that rice cultivars varied widely in their native agro-morphic parameters and grain $\mathrm{Zn}$ and Fe contents among the categories of locals, HYVs, hybrids and aromatics in native soil marginally deficient in available Zn. Application of Zn fertilizers both as basal as well as soil plus foliar application significantly influenced all the agro-morphological parameters tested viz., number of tillers per hill, plant height, panicle length, test weight, grain and straw yield of rice. The magnitude of increase in grain yield over control was $29 \%$ and $22 \%$ in soil plus foliar and only soil application of $\mathrm{Zn}$ respectively. Therefore, it can be opined that soil plus foliar application of $\mathrm{Zn}$ was very effective than soil alone application. Two foliar spraying of $\mathrm{Zn}$ (@ $0.5 \% \mathrm{ZnSO}_{4} .7 \mathrm{H}_{2} \mathrm{O}$ ) along with basal application (@20 kg Zn ha-1) increased the grain Zn content to the level of two to three times, while only soil applied Zn increased it very slightly indicating that basal application of Zn showed a trend to increase the grain yield, whereas, soil plus foliar application was proven to enhance the grain $\mathrm{Zn}$ content i.e. to increase the quality of the final produce. 


\section{REFERENCES}

Alloway, B.J. 2004. Zinc in Soils and Crop Nutrition. IZA Publications, International Zinc Association, Brussels, pp: 1-116.

Bandara, W.M.J. and Silva, L.C. 2000. Rice crop response to zinc application in low humic gley soils of low country intermediate zone. Journal of Soil Science Society Sri Lanka, 12: 40-50.

Cakmak, I. 2008. Enrichment of cereal grains with Zn: Agronomic or genetic biofortification? Plant Soil, 302: 1-17.

Cakmak, I., Yilmaz, A., Ekiz, H., Torun, B., Erenoglu, B. and Braun, H. J. 1996. Zn deficiency as a critical nutritional problem in wheat production in Central Anatolia. Plant Soil, 180: 165-172.

Dobermann, A. and Fairhurst, T. 2000. Rice: Nutrient disorders and nutrient management. IRRI, Manila, Philippines.

Fageria, N.K. and Baligar, V.C. 2005. Growth components and Zn recovery efficiency of upland rice genotypes. Pesq. Agropec. Bras., 40(12): 1211-1215.

Fageria, N.K., Baligar, V.C. and Clark, R.B. 2002. Micronutrients in crop production. Advanced Agronomy, 77: 185-268.

Goirdano, P.M. and Mortvedt, J.J. 1972. Rice response to zinc in flooded and nonflooded soil. AgronomyJournal, 64: 521-524.

Graham, R.D. and Rengel, Z. 1993. Genotypic variation in Zn uptake and utilization by plants. In: Zn in Soils and Plants, Ed. A.D. Robson. Kluwer Academic Publishers, Dordrecht. pp. 107-118.

Graham, R.D., Senadhira, D., Beebe, S.E., Iglesias, C. and Ortiz-Monasterio, I. 1999. Breeding for micronutrient density in edible portions of staple food crops: Conventional approaches. Field Crops Research, 60: 57-80.

Lindsay, W.L. and Norvell, W.A. 1978. Development of a DTPA soil test for zinc, iron, manganese and copper. Soil Science Society of American Journal, 42: 421-428.

Mandal, B., Chatterjee, J., Hazra, G.C. and Mandal, L.N. 1992. Effect of preflooding on transformation of applied zinc and its uptake by rice in lateritic soils. Soil Science, 153: 250-257.

Page, A.L., Miller, R.H. and Keeney, D.R. 1982. Methods of Soil Analysis, Part-2, Second Edition, Soil Science Society of American Journal, Madison, Wisconsin, USA.

Pal, S., Banerjee, H., Basu, B. and Maiti, S. 2008. Studies on nutrient management practice in rice-rice crop sequence under new alluvial zone of West Bengal. Oryza, 45(1): 125128.

Rahman, M.T., Jahiruddin, M., Humauan, M.R., Alam, M.J. and Khan, A.A. 2008. Effect of sulphur and zinc on growth, yield and nutrient uptake of boro rice (cv. BRRI DHAN 29). Journal of Soil Nature, 2(3): 10-15.

Reddy, A.M., Shankhdhar, D., Shankhdhar, S.C. and Mani, S.C. 2010. Effect of aerobic cultivation on yield, biochemical and physiological characters of selected rice genotypes. Oryza, 47(1): 22-28. 
Rengel, Z., Romheld, V. and Marschner, H. 1998. Uptake of zinc and iron by wheat genotypes differing in tolerance to zinc deficiency. Journal of Plant Physiology, 152: 433-438.

Senasdhira, D. and Graham, R.D. 1999. Genetic variation in iron and zinc concentrations in brown rice. Micronutrients and Agrilculture, 3: 4-5.

Singh, M.V. 2009. Micronutrient nutritional problems in soils of India and improvement for human and animal health. Indian Journal of Fertilizer, 5(4): 11-16, 19-26 and 56.

Vallee, B.L., Wacker, W.E.C. 1970. Metalloproteins. In H. Neurath (ed.). The proteins (2nd ed.) Vol 5. Academic Press, New York. p. 192.

Walkley, A.J. and Black, I.A. 1934. Estimation of soil organic carbon by the chromic acid titration method. Soil Science, 37: 29-38.

Yang, X.E., Chen, W.R. and Feng, Y. 2007. Improving human micronutrient nutrition through biofortification in the soil-plant system: China as a case study. Env. Geochem. Health, 29: 413-428.

Zou, C.Q., Gao, X.P. and Zhang, F.S. 2007. Micronutrient deficiencies in crop production in China. In: Alloway, B. (Ed) Micronutrient Deficiencies in Global Crop Production. 
Table 1: Influence of Zn fertilization on number of tillers per hill at maximum tillering stage, plant height and panicle length of the rice cultivars at harvesting stage.

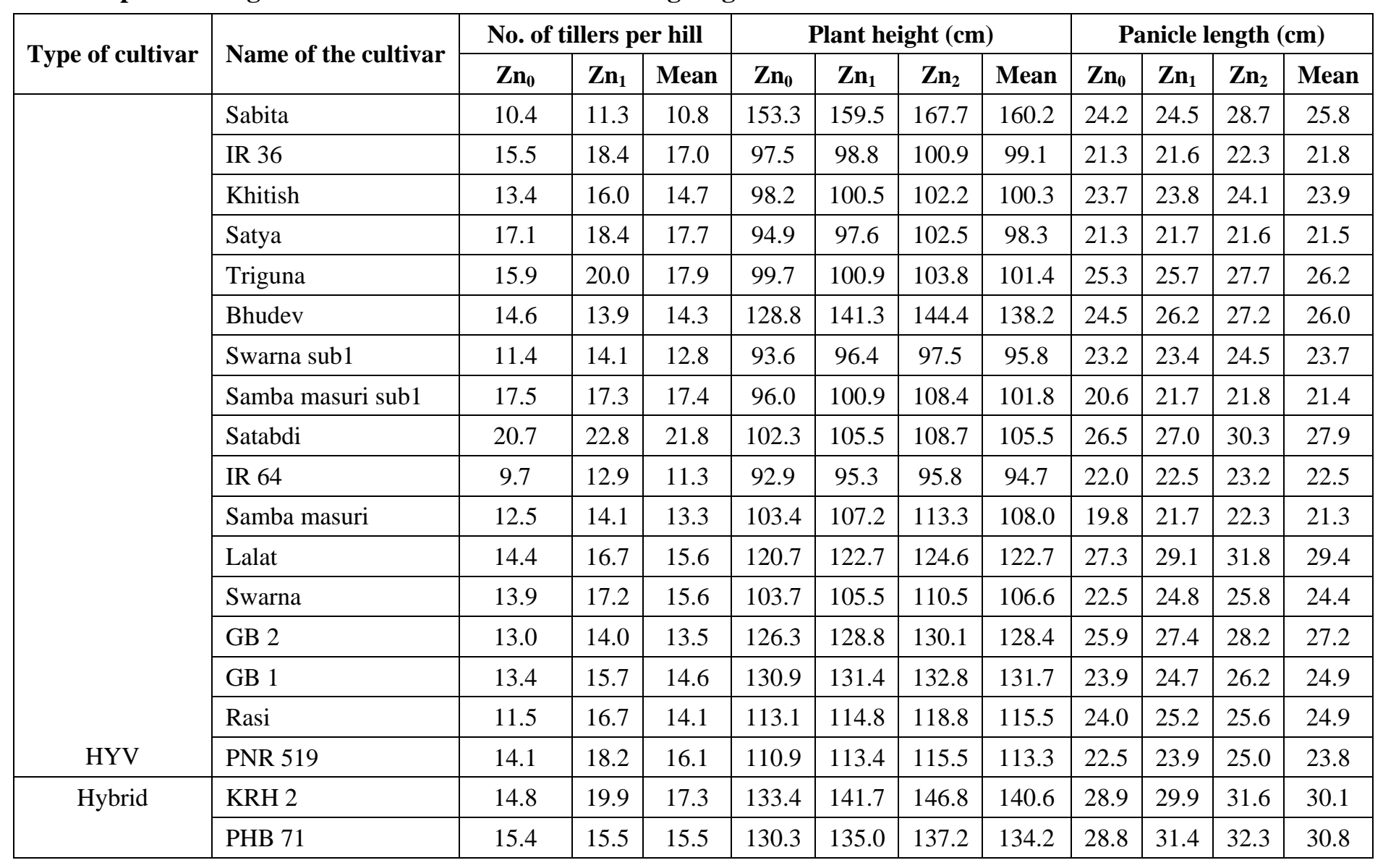




\begin{tabular}{|c|c|c|c|c|c|c|c|c|c|c|c|c|}
\hline \multirow{3}{*}{ Type of cultivar } & \multirow{2}{*}{ Name of the cultivar } & \multicolumn{3}{|c|}{ No. of tillers per hill } & \multicolumn{4}{|c|}{ Plant height (cm) } & \multicolumn{4}{|c|}{ Panicle length $(\mathrm{cm})$} \\
\hline & & $\mathbf{Z n}_{0}$ & $\mathrm{Zn}_{1}$ & Mean & $\mathbf{Z n}_{0}$ & $\mathrm{Zn}_{1}$ & $\mathbf{Z n}_{2}$ & Mean & $\mathbf{Z n}_{0}$ & $\mathbf{Z n}_{1}$ & $\mathrm{Zn}_{2}$ & Mean \\
\hline & PA 6444 & 16.1 & 17.8 & 17.0 & 130.2 & 132.0 & 133.8 & 132.0 & 23.6 & 26.3 & 27.3 & 25.7 \\
\hline \multirow[b]{2}{*}{ Local } & FR 43B & 10.9 & 13.6 & 12.3 & 172.0 & 178.3 & 185.9 & 178.7 & 23.5 & 27.1 & 27.0 & 25.9 \\
\hline & Kalma 222 & 12.4 & 14.3 & 13.4 & 183.4 & 191.5 & 203.1 & 192.7 & 24.2 & 26.4 & 26.7 & 25.8 \\
\hline \multirow{9}{*}{ Aromatic } & Gayasur & 12.3 & 12.7 & 12.5 & 140.9 & 144.6 & 148.6 & 144.7 & 24.0 & 25.3 & 26.3 & 25.2 \\
\hline & Gobindabhog & 15.0 & 17.3 & 16.2 & 139.5 & 153.3 & 154.1 & 148.9 & 24.4 & 25.5 & 25.5 & 25.1 \\
\hline & Badshabhog & 12.2 & 15.6 & 13.9 & 148.9 & 154.5 & 154.8 & 152.7 & 24.2 & 26.7 & 28.8 & 26.6 \\
\hline & PNR 546 & 11.7 & 16.4 & 14.0 & 104.9 & 109.4 & 111.3 & 108.5 & 30.3 & 32.3 & 33.7 & 32.1 \\
\hline & Mean & 13.8 & 16.2 & 15.0 & 121.1 & 125.4 & 129.0 & 125.2 & 24.2 & 25.6 & 26.7 & 25.5 \\
\hline & & $\operatorname{SEm}( \pm)$ & \multicolumn{2}{|c|}{$\operatorname{LSD}(0.05)$} & \multicolumn{2}{|c|}{ SEm ( \pm ) } & \multicolumn{2}{|c|}{$\operatorname{LSD}(0.05)$} & \multicolumn{2}{|c|}{$\operatorname{SEm}( \pm)$} & \multicolumn{2}{|c|}{$\operatorname{LSD}(0.05)$} \\
\hline & Variety & 0.49 & \multicolumn{2}{|c|}{1.38} & \multicolumn{2}{|c|}{0.48} & \multicolumn{2}{|c|}{1.35} & \multicolumn{2}{|c|}{0.16} & \multicolumn{2}{|c|}{0.46} \\
\hline & Zn & 0.2 & \multicolumn{2}{|c|}{0.79} & \multicolumn{2}{|c|}{0.12} & \multicolumn{2}{|c|}{0.39} & \multicolumn{2}{|c|}{0.1} & \multicolumn{2}{|c|}{0.32} \\
\hline & VarietyxZn & 0.77 & \multicolumn{2}{|c|}{2.17} & \multicolumn{2}{|c|}{0.62} & \multicolumn{2}{|c|}{1.74} & \multicolumn{2}{|c|}{0.3} & \multicolumn{2}{|c|}{0.85} \\
\hline
\end{tabular}


Table 2: Influence of $\mathrm{Zn}$ fertilization on test weight (g), grain yield (q/ha) and straw yield (q/ha) of the rice cultivars.

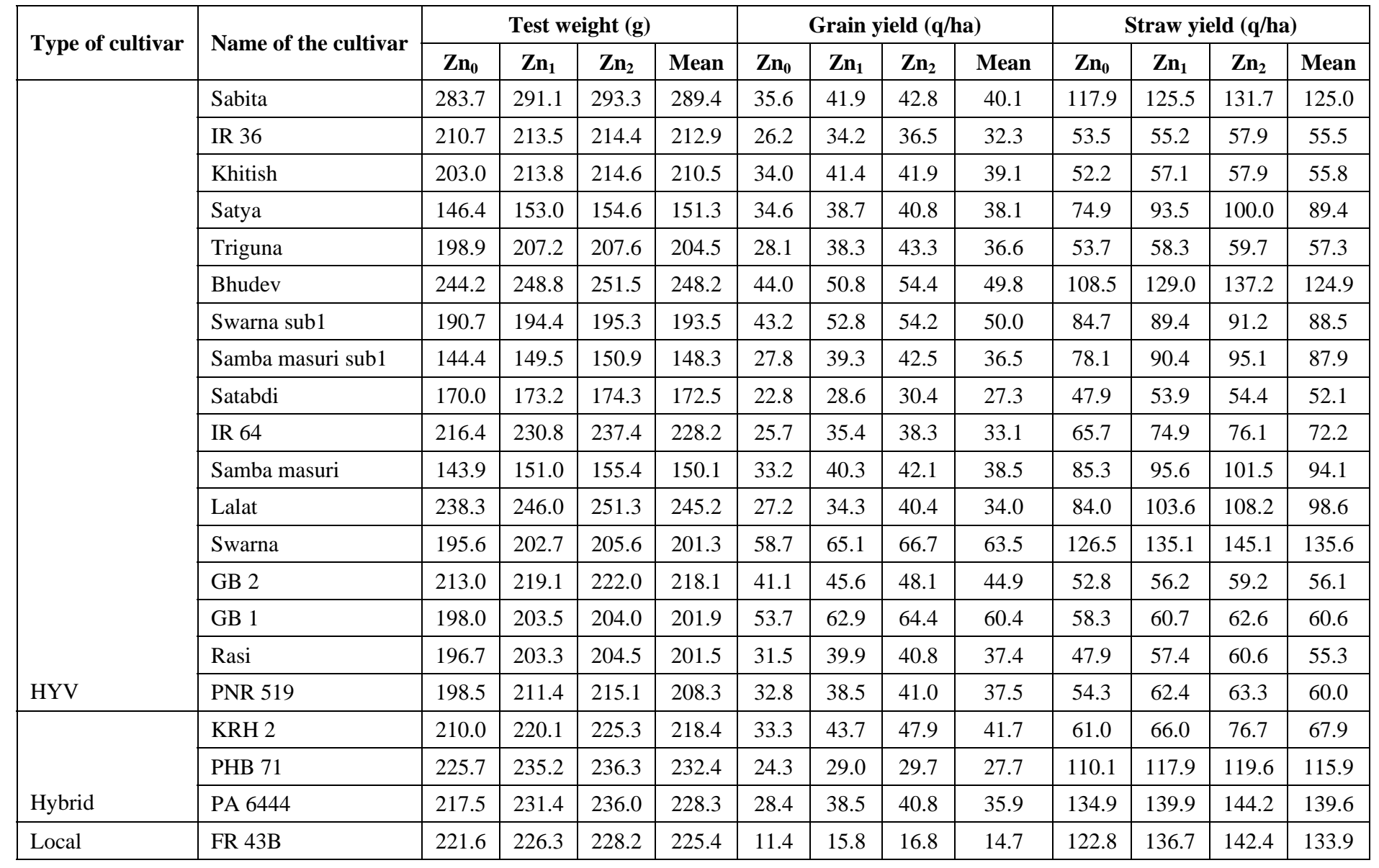




\begin{tabular}{|c|c|c|c|c|c|c|c|c|c|c|c|c|c|}
\hline \multirow{3}{*}{ Type of cultivar } & \multirow{2}{*}{ Name of the cultivar } & \multicolumn{4}{|c|}{ Test weight (g) } & \multicolumn{4}{|c|}{ Grain yield (q/ha) } & \multicolumn{4}{|c|}{ Straw yield (q/ha) } \\
\hline & & $\mathbf{Z n}_{0}$ & $\mathbf{Z n}_{1}$ & $\mathbf{Z n}_{2}$ & Mean & $\mathbf{Z n}_{0}$ & $\mathbf{Z n}_{1}$ & $\mathbf{Z n}_{2}$ & Mean & $\mathbf{Z n}_{0}$ & $\mathrm{Zn}_{1}$ & $\mathbf{Z} \mathbf{n}_{2}$ & Mean \\
\hline & Kalma 222 & 249.9 & 254.9 & 257.3 & 254.0 & 10.1 & 12.6 & 12.8 & 11.9 & 104.2 & 121.7 & 128.7 & 118.2 \\
\hline \multirow{9}{*}{ Aromatic } & Gayasur & 120.3 & 128.3 & 132.9 & 127.1 & 19.6 & 25.3 & 26.5 & 23.8 & 85.7 & 106.0 & 111.2 & 101.0 \\
\hline & Gobindabhog & 100.4 & 107.0 & 109.9 & 105.8 & 22.6 & 26.1 & 27.4 & 25.4 & 98.7 & 111.5 & 115.8 & 108.7 \\
\hline & Badshabhog & 95.3 & 99.4 & 100.8 & 98.5 & 24.3 & 27.1 & 28.3 & 26.6 & 116.9 & 124.9 & 129.2 & 123.7 \\
\hline & PNR 546 & 195.6 & 203.5 & 206.8 & 202.0 & 24.2 & 27.6 & 28.5 & 26.8 & 57.8 & 69.2 & 71.9 & 66.3 \\
\hline & Mean & 193.4 & 200.7 & 203.3 & 199.1 & 30.7 & 37.5 & 39.5 & 35.9 & 82.2 & 92.0 & 96.2 & 90.2 \\
\hline & & \multicolumn{2}{|c|}{ SEm ( $( \pm)$} & \multicolumn{2}{|c|}{ LSD $(0.05)$} & \multicolumn{2}{|c|}{$\operatorname{SEm}( \pm)$} & \multicolumn{2}{|c|}{$\operatorname{LSD}(0.05)$} & \multicolumn{2}{|c|}{ SEm $( \pm)$} & \multicolumn{2}{|c|}{ LSD $(0.05)$} \\
\hline & Variety & \multicolumn{2}{|c|}{1.1} & \multicolumn{2}{|c|}{3.08} & \multicolumn{2}{|c|}{0.37} & \multicolumn{2}{|c|}{1.04} & \multicolumn{2}{|c|}{0.88} & \multicolumn{2}{|c|}{2.46} \\
\hline & $\mathrm{Zn}$ & \multicolumn{2}{|c|}{0.39} & \multicolumn{2}{|c|}{1.28} & \multicolumn{2}{|c|}{0.19} & \multicolumn{2}{|c|}{0.61} & \multicolumn{2}{|c|}{0.32} & \multicolumn{2}{|c|}{1.04} \\
\hline & VarietyxZn & \multicolumn{2}{|c|}{1.85} & \multicolumn{2}{|c|}{5.16} & \multicolumn{2}{|c|}{0.6} & \multicolumn{2}{|c|}{1.68} & \multicolumn{2}{|c|}{1.15} & \multicolumn{2}{|c|}{3.22} \\
\hline
\end{tabular}


Table 3: Influence of $\mathrm{Zn}$ fertilization on $\mathrm{Zn}$ and Fe content (mg kg $\left.\mathbf{~}^{-1}\right)$ in brown rice.

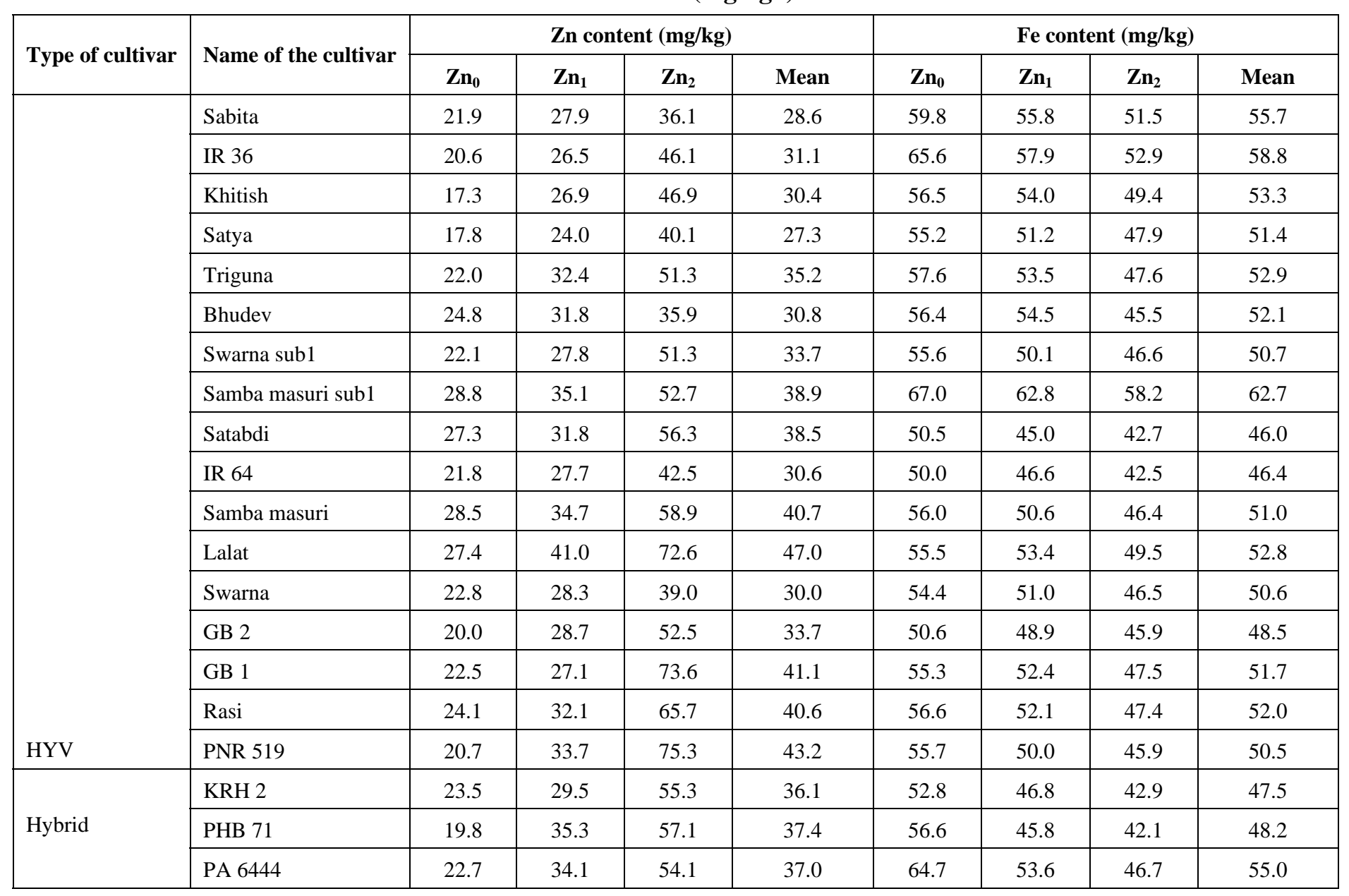




\begin{tabular}{|c|c|c|c|c|c|c|c|c|c|}
\hline \multirow[b]{2}{*}{ Local } & FR 43B & 25.5 & 32.4 & 49.0 & 35.6 & 67.8 & 62.5 & 59.3 & 63.2 \\
\hline & Kalma 222 & 27.1 & 30.9 & 57.4 & 38.5 & 66.1 & 57.8 & 53.6 & 59.2 \\
\hline \multirow{9}{*}{ Aromatic } & Gayasur & 25.4 & 30.4 & 43.3 & 33.1 & 72.1 & 67.8 & 62.9 & 67.6 \\
\hline & Gobindabhog & 25.8 & 27.2 & 43.7 & 32.2 & 72.6 & 57.7 & 51.4 & 60.6 \\
\hline & Badshabhog & 27.4 & 28.7 & 43.5 & 33.2 & 69.6 & 58.2 & 53.4 & 60.4 \\
\hline & PNR 546 & 32.7 & 38.2 & 53.0 & 41.3 & 73.7 & 67.6 & 56.9 & 66.0 \\
\hline & Mean & 23.8 & 30.9 & 52.0 & 35.6 & 59.8 & 54.1 & 49.3 & 54.4 \\
\hline & & \multicolumn{2}{|c|}{$\operatorname{SEm}( \pm)$} & \multicolumn{2}{|c|}{ LSD (0.05) } & \multicolumn{2}{|c|}{$\operatorname{SEm}( \pm)$} & \multicolumn{2}{|c|}{$\operatorname{LSD}(0.05)$} \\
\hline & Variety & \multicolumn{2}{|c|}{0.50} & \multicolumn{2}{|c|}{1.41} & \multicolumn{2}{|c|}{0.14} & \multicolumn{2}{|c|}{0.38} \\
\hline & $\mathrm{Zn}$ & \multicolumn{2}{|c|}{0.16} & \multicolumn{2}{|c|}{0.53} & \multicolumn{2}{|c|}{0.04} & \multicolumn{2}{|c|}{0.14} \\
\hline & VarietyxZn & \multicolumn{2}{|c|}{0.89} & \multicolumn{2}{|c|}{2.49} & \multicolumn{2}{|c|}{0.24} & \multicolumn{2}{|c|}{0.67} \\
\hline
\end{tabular}




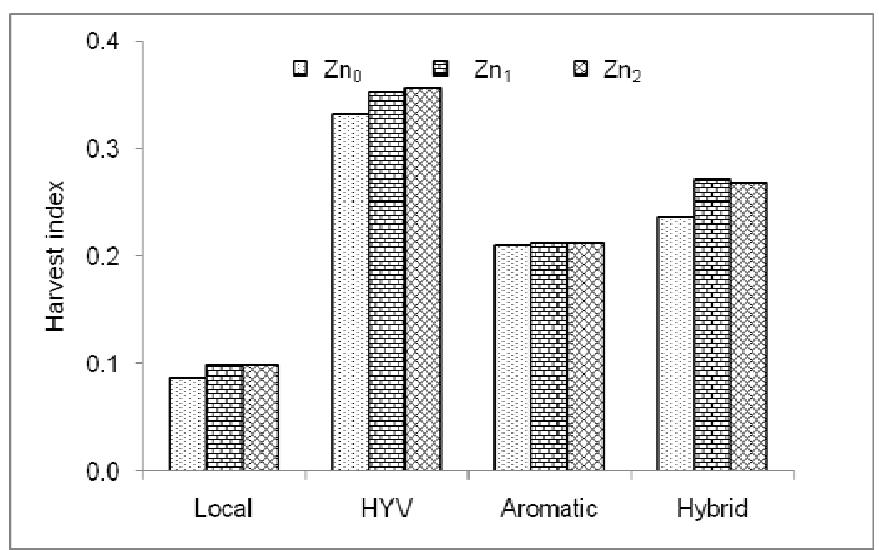

Figure 1: Variation in harvest index of the rice cultivars with different levels of Zn

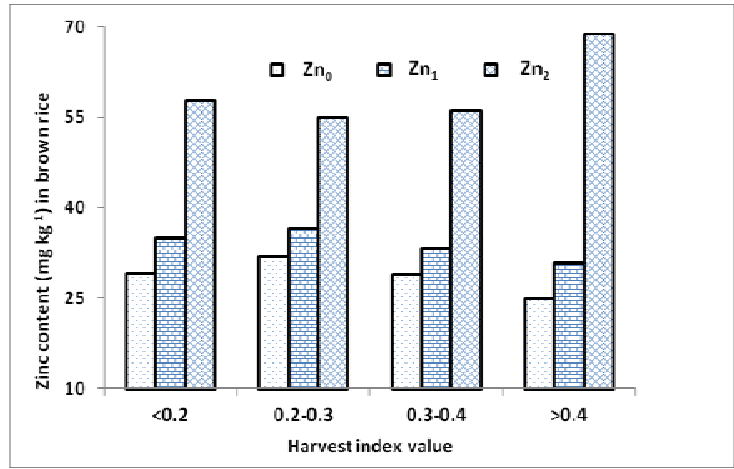

Figure 2: Relationship between harvest index and Zn content in brown rice with different levels of $\mathrm{Zn}$

1. Since the Jouranl is for a greater audience of readers across many countries use of terms, units etc should be international.

2. Title says quality parameters but no such parameters were evaluated except grain $\mathrm{Zn}$ and Fe content. Hence re wording of title is suggested.

3. The LSD values given are for comparing mean effects or treatments effects. It has to be clearly indicated. The LSD value for variety is I believe can be used only to compare variety groups and not individual varieties.

4. No indicationof the Figure 2 appear in the text.

5. Fe and Zn content variation in grain has to be given an important consideration as the people wanted grains having both Fe and Zn. Therefore authors should be encouraged to discuss the optimum way of having both in the grain. But he emphasize only on $\mathrm{Zn}$.

6. Author has stated that he observed Brown Plant Hopper at early plant growth stage. I believe this must be thrips and not the BPH which usually attack the grown up plants with dense canopy when RH is high. 